Volume 13, Nomor 1, Mei 2021, pp 118-133 Copyright (C 2017

Jurnal Akuntansi, Program Studi Akuntansi, Fakultas Bisnis,

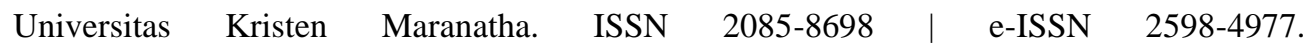

http://journal.maranatha.edu

\title{
Kegiatan Corporate Social Responsibility dan Prospek Kinerja Keuangan Perusahaan Sumber Daya Alam di Indonesia, Singapura, dan Malaysia
}

\author{
Janita Suryani Muliate ${ }^{1}$ \\ Universitas Prasetiya Mulya \\ (Jl. BSD Raya Utama, Kab.Tangerang ) \\ janita.muliate@student.pmsbe.ac.id \\ Silvi Suhendro ${ }^{2}$ \\ Universitas Prasetiya Mulya \\ (Jl. BSD Raya Utama, Kab.Tangerang ) \\ silvi.suhendro@student.pmsbe.ac.id
}

\author{
Rinaningsih $^{3}$ \\ Universitas Prasetiya Mulya \\ (Jl. BSD Raya Utama, Kab.Tangerang ) \\ rinaningsih@pmbs.ac.id \\ Vania Pradipta Gunawan ${ }^{4}$ \\ Universitas Prasetiya Mulya \\ (Jl. BSD Raya Utama, Kab.Tangerang ) \\ vania.gunawan@pmbs.ac.id
}

\begin{abstract}
This research aims to determine the influence of implementation and reporting of Corporate Social Responsibility (CSR) activities towards the prospect of corporate financial performance. The samples used in this research is the company of the natural resources sector operating in Indonesia, Singapore, and Malaysia from 2011 to 2017 with total samples of 25 companies and 96 observations. The data obtained is processed using quantitative research method. In this research, it is known that there are several results explaining the relationship between implementation and reporting of CSR activities to the company's financial performance in the future which is proscribed with return on asset, return on equity, cash flow from operating activities, and Tobin's $Q$. The results of the study also showed significant negative results between the reporting and the implementation of CSR activities with the company's financial performance in the future. This results showed that CSR activities in Indonesia, Singapore, and Malaysia were a charity activity or just to fulfil governance's rules.
\end{abstract}

Keywords: Corporate Social Responsibility, Firm's Financial Performance, and Natural Resources Industry

\begin{abstract}
Abstrak
Penelitian ini memiliki tujuan untuk mengetahui pengaruh pelaksanaan dan pelaporan kegiatan tanggung jawab sosial perusahaan atau Corporate Social Responsibility (CSR) terhadap prospek kinerja keuangan perusahaan. Sampel yang digunakan dalam pelaksanaan penelitian ini adalah perusahaan yang tergabung dalam sektor sumber daya alam (SDA) yang melaksanakan kegiatan operasionalnya di Indonesia, Singapura, dan Malaysia dari 118
\end{abstract}


tahun 2011 sampai dengan tahun 2017 dengan total sampel sebesar 25 perusahaan dan 96 data observasi. Data yang didapatkan diolah dengan menggunakan metode penelitian kuantitatif. Pada penelitian ini diketahui bahwa terdapat beberapa hasil yang menjelaskan hubungan yang antara pelaksanaan dan pelaporan kegiatan CSR terhadap prospek kinerja keuangan perusahaan yang diproksikan dengan return on asset, return on equity, cash flow from operating activities, dan nilai Tobin's Q. Selain itu, dari hasil penelitian ini juga menunjukkan adanya hasil negatif signifikan antara pelaporan dan pelaksanaan kegiatan CSR dengan prospek kinerja keuangan perusahaan yang mengindikasikan bahwa pelaksanaan kegiatan CSR di ketiga negara merupakan suatu kegiatan yang bersifat sukarela atau hanya untuk memenuhi peraturan pemerintah.

\section{Kata Kunci: Corporate Social Responsibility, Kinerja Keuangan Perusahaan, dan Sumber Daya Alam}

\section{Pendahuluan}

Berdasarkan data yang dirilis pada ASEAN Ministerial Meeting on Environment (AMME) yang dilakukan oleh Association of Southeast Asian Nations (ASEAN) pada tahun 2018, negara ASEAN merupakan kawasan yang memiliki kekayaan sumber daya alam yang sangat berlimpah dan dapat digunakan untuk memenuhi kebutuhan negara itu sendiri bahkan dapat memenuhi kebutuhan dunia (ASEAN Cooperation on Environment, 2019). Berlimpahnya kekayaan alam yang dimiliki negara ASEAN ini membuat negara ASEAN harus menghadapi tantangan besar dalam menjaga keseimbangan kelestarian lingkungan dan pembangunan ekonomi (ASEAN Cooperation on Environment, 2019). Terdapat beberapa fenomena kerusakan lingkungan yang terjadi di negara ASEAN, salah satunya adalah deforestasi hutan yang terjadi di Indonesia yang mana deforestasi ini terjadi akibat adanya pembukaan lahan perkebunan kelapa sawit dan kedelai untuk kepentingan kegiatan usaha.

Pentingnya pelaksanaan kegiatan CSR juga telah disadari oleh pihak pemerintah Indonesia, Singapura, dan Malaysia. Kesadaran pihak pemerintahan ketiga negara ditunjukkan dengan adanya peraturan yang mengatur mengenai pelaksanaan dan pelaporan kegiatan CSR di ketiga negara tesebut. Salah satu hasil penelitian terdahulu menemukan bahwa pengungkapan kegiatan CSR di Asia masih lebih rendah dibandingkan dengan pengungkapan kegiatan CSR di Amerika dan Eropa. Berdasarkan laporan yang dikeluarkan oleh KPMG (2008, 2013) diketahui bahwa terdapat peningkatan pada pengungkapan laporan CSR di beberapa negara seperti Amerika, Inggris, Perancis, Jerman, dan Jepang. Namun, di negara Asia hanya terdapat beberapa negara yang mulai mengungkapkan laporan CSR, seperti Jepang, Korea Selatan, China, India, Indonesia, Malaysia, dan Singapura. Selain negara Jepang dan Korea Selatan, pelaporan CSR di negara Asia lainnya masih dalam tahap awal (Laskar dan Maji, 2018).

Selain mengatur mengenai pelaksanaan kegiatan CSR, ketiga negara tersebut (Indonesia, Singapura, dan Malaysia) juga telah memberikan acuan mengenai pelaporan kegiatan CSR. Acuan mengenai pelaporan kegiatan CSR ini disesuaikan dengan standar dari framework yang dikeluarkan oleh Global Reporting Initiative (GRI). GRI adalah organisasi internasional yang bersifat independen yang membantu pihak organisasi dan pemerintahan untuk dapat mengerti dan mengkomunikasikan dampak dalam isu perubahan iklim, hak asasi manusia, dan 
korupsi. Berdasarkan pengelompokkan yang dilakukan oleh GRI terdapat tiga aspek utama dalam menjalankan kegiatan CSR yaitu ekonomi, lingkungan, dan sosial. Pada kelompok ekonomi terdapat beberapa pelaksanaan kegiatan yang diatur pada framework ini, seperti performa perusahaan dan korupsi. Pada aspek lingkungan terdapat beberapa kegiatan yang berhubungan dengan energi dan material, sedangkan pada kelompok sosial membahas mengenai kegiatan yang berhubungan dengan kesejahteraan karyawan seperti keamanan dan kesehatan karyawan, gaji karyawan, dan pelatihan karyawan.

$$
\text { Adanya framework yang }
$$

dikeluarkan oleh GRI, tidak hanya membahas mengenai kondisi lingkungan, framework ini juga membahas mengenai aspek ekonomi. Aspek ekonomi ini salah satunya terdiri dari kegiatan anti korupsi. Ditemukan bahwa di ketiga negara masih terdapat banyak tindak pidana korupsi yang dilakukan oleh para pelaku usaha. Salah satunya adalah tindak pidana korupsi yang terjadi di Malaysia, yaitu kasus MDB atau Malaysia Development Berhad. Berdasarkan berita yang telah dilansir oleh CNN Indonesia, bahwa tindak pidana korupsi ini telah menjerat salah satu petinggi di negara tersebut dan telah menggelapkan dana sebesar USD 1.000.000.000. Pada kasus ini tidak hanya menjerat petinggi negara tersebut, tetapi juga terdapat pelaku usaha yang ikut bergabung dalam tindak pidana korupsi ini.

Fenomena mengenai kerusakan lingkungan dan korupsi yang terjadi di Indonesia dan Malaysia ini menunjukkan bahwa perusahaan masih belum menerapkan konsep 3P (Profit, People, and Planet) atau triple bottom line (TBL) secara utuh. Perusahaan hanya mementingkan salah satu aspek dari 3P yaitu, profit (laba) perusahaan. KsiężaK dan Fischbach (2017) menyatakan bahwa 3P berkaitan erat dengan kegiatan Corporate Social Responsibility (CSR) dengan melaksanakan kegiatan CSR perusahaan telah menerapkan seluruh aspek dari konsep 3P. Friedman (1970) menyatakan bahwa CSR merupakan salah satu alat dalam pelaksanaan strategi perusahaan untuk mencapai tujuan ekonomi perusahaan dan meningkatkan daya tarik para pemangku kepentingan yang dikenal dengan instrumental theory. Di lain sisi, Yakovleva (2006), Nugrahanti dan Maharani (2013) menyatakan bahwa pada saat ini kegiatan CSR bukan hanya sebagai kegiatan ekonomi untuk menghasilkan keuntungan bagi perusahaan, tetapi perusahaan juga mempunyai tanggung jawab kepada masyarakat dan lingkungan.

Hubungan antara kinerja keuangan dengan pengungkapan kegiatan CSR telah menimbulkan begitu banyak pertanyaan yang menyebabkan timbulnya beberapa hasil pemikiran (Widaryanti, 2007). Herremans, Akathaporn, dan Mcinnes (1993) mengemukakan tiga pemikiran mengenai hubungan pelaksanaan CSR dengan kinerja keuangan. Pertama, kegiatan CSR akan meningkatkan beban tambahan bagi perusahaan dan menghilangkan peluang perolehan laba bagi perusahaan. Kedua, biaya yang dikeluarkan untuk kegiatan CSR akan sebanding dengan laba yang akan dihasilkan oleh perusahaan dikarenakan adanya keuntungan efisiensi yang ditimbulkan oleh biaya kegiatan CSR. Bruyn (1987) dalam Herremans et al. (1993) mengungkapkan bahwa investasi yang dilakukan dengan dasar sosial akan meningkatkan kemampuan investor dalam memprediksi hasil ekonomi. Ketiga, perusahaan yang melakukan kewajiban sosial menunjukkan bahwa pihak manajemen perusahaan memiliki kemampuan yang superior dan mampu memberikan hasil kinerja yang baik.

Adanya fenomena yang terjadi seperti yang telah dijelaskan sebelumnya masih menunjukkan rendahnya kesadaran pelaku bisnis dalam melaksanakan kegiatan CSR. Hal ini juga ditunjukkan dari hasil penelitian ini yang menemukan bahwa kegiatan CSR di ketiga negara merupakan kegiatan yang bersifat sukarela (charity 
activities) dengan jumlah observasi sebesar 96 data observasi dari tahun 2011 hingga tahun 2017 . Berdasarkan hasil penelitian ini terdapat beberapa kontribusi yang dapat diterima oleh pihak regulator, investor, manajemen, dan juga akademisi. Pihak regulator dapat lebih tegas dalam memberikan sanksi kepada para pelaku usaha yang melanggar peraturan yang telah ada. Selain itu, investor juga dapat membantu mendorong terlaksananya kegiatan CSR dengan cara lebih memperhatikan perusahaan yang telah melaksanakan kegiatan CSR. Penelitian ini juga berkontribusi untuk pihak manajemen untuk mendukung manajemen agar dapat mempertimbangkan pelaksanaan kegiatan CSR untuk keunggulan perusahaan (competitive advantage), serta bagi pihak akademisi untuk dapat membantu memahami mengenai hubungan kegiatan CSR dan prospek kinerja keuangan perusahaan.

\section{Rumusan Masalah dan Tujuan Penelitian}

Berdasarkan uraian diatas maka perumusan masalah dalam penelitian ini adalah:

1. Apakah pengeluaran biaya untuk pelaksanaan kegiatan tanggung jawab sosial perusahaan saat ini berpengaruh signifikan negatif terhadap prospek kinerja

keuangan perusahaan?

2. Apakah pengeluaran biaya untuk pelaksanaan kegiatan tanggung jawab sosial perusahaan saat ini berpengaruh signifikan positif terhadap prospek kinerja keuangan perusahaan?

3. Apakah pengungkapan kegiatan tanggung jawab sosial perusahaan saat ini berpengaruh signifikan positif terhadap prospek kinerja keuangan perusahaan?

Pada penelitian ini memiliki dua tujuan utama yaitu:

1. Menguji pengaruh pengeluaran biaya untuk pelaksanaan kegiatan tanggung jawab sosial perusahaan saat ini terhadap prospek kinerja keuangan perusahaan.

2. Menguji pengaruh pengungkapan kegiatan tanggung jawab sosial perusahaan saat ini terhadap prospek kinerja keuangan perusahaan.

Jurnal ini disusun sesuai dengan bagian sebagai berikut, bagian 1 membahas mengenai latar belakang dari penelitian ini, bagian 2 membahas mengenai telaah literatur dan pengembangan hipotesis, bagian 3 membahas mengenai metode penelitian, dan bagian akhir dari jurnal ini membahas mengenai hasil dari penelitian ini beserta dengan kesimpulan dari penelitian ini.

\section{Kerangka Teoretis dan Hipotesis}

Berikut merupakan kerangka penelitian yang digunakan dalam penelitian ini:

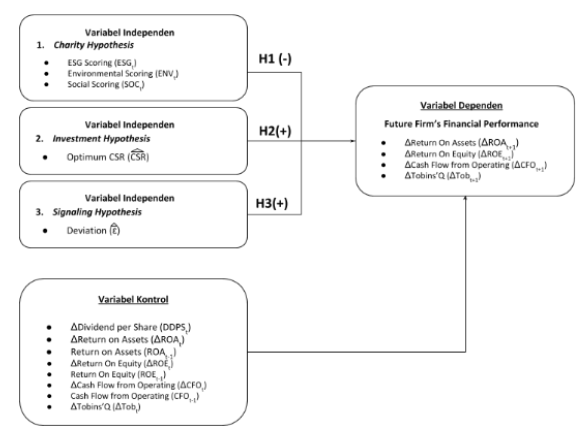

Gambar 1

Kerangka Penelitian

Sumber: data yang diolah, 2020

\section{Tinjauan Pustaka}

\section{Pengeluaran Biaya untuk Kegiatan Tanggungjawab Sosial dan Prospek Kinerja Keuangan (Charity Hypothesis)}

Lys et al. (2015) menyatakan bahwa hipotesis ini terjadi ketika pengeluaran biaya kegiatan CSR (dalam bentuk apapun) tidak memiliki pengaruh signifikan $(\alpha=0)$ atau signifikan negatif $(\alpha<0)$ terhadap 
prospek kinerja keuangan perusahaan. Widiastuty dan Soewarno (2019) menyimpulkan bahwa kegiatan CSR tidak hanya berorientasi pada tujuan untuk memberikan sinyal kepada para stakeholder, melainkan juga untuk menjaga kesejahteraan sosial dan lingkungan. Lys et al. (2015) juga menemukan bahwa kegiatan tanggung jawab sosial perusahaan memiliki tujuan utama sebagai kegiatan sosial. Tujuan ini menunjukkan bahwa pelaku usaha melaksanakan kegiatan CSR sematamata hanya untuk melakukan kegiatan sukarela (charity activities).

Hong, Kubik, dan Scheinkman (2012) menyatakan bahwa pelaku usaha yang mempunyai nilai arus kas yang cukup tinggi akan memiliki keinginan untuk melakukan kegiatan CSR. Hal ini terjadi dikarenakan pelaku usaha memiliki sumber dana yang cukup besar sehingga perusahaan melakukan kegiatan CSR tanpa mempertimbangkan return yang akan didapatkan di masa depan. Stakeholder theory juga menjelaskan bahwa perusahaan akan memberikan respon pada keinginan dari masing-masing pemangku kepentingan, salah satunya adalah untuk meningkatkan competitive advantage perusahaan. Peningkatan competitive advantage perusahaan ini dilakukan dengan melaksanakan kegiatan CSR perusahaan dan hal ini nantinya akan menambah nilai dan reputasi perusahaan di kalangan masyarakat.

H1 : Pengeluaran biaya untuk kegiatan tanggung jawab sosial memiliki pengaruh signifikan negatif terhadap prospek kinerja keuangan perusahaan (Charity Hypothesis).

2.Pengeluaran Biaya untuk Kegiatan CSR dan Prospek Kinerja Keuangan Perusahaan (Investment in CSR)

Margolis et al. (2007) menyimpulkan bahwa komitmen yang kuat dalam melaksanakan kegiatan CSR sebagai inisiatif perusahaan akan meningkatkan performa keuangan perusahaan di masa depan. Penelitian yang dilakukan oleh Lys et al. (2015) juga menunjukkan adanya hubungan positif antara pengeluaran untuk kegiatan tanggung jawab sosial perusahaan dengan prospek kinerja keuangan perusahaan. Hasil penelitian ini didasari dengan adanya motivasi perusahaan untuk menambah nilai ekonomi perusahaan. Hasil penelitian yang dilakukan oleh Janamrung dan Issarawornrawanich (2015) juga menemukan bahwa pelaku usaha yang mempunyai tingkat pendanaan CSR yang cenderung lebih besar akan mempunyai performa keuangan yang lebih baik ditunjukkan dengan nilai ROA perusahaan yang tinggi. Dhaliwal, Tsang, dan Yang (2011) dalam Lys et al. (2015) menemukan bahwa pelaksanaan kegiatan CSR secara sukarela akan memberikan dampak pada penurunan cost of capital perusahaan, peningkatan pada kepemilikan investor, dan cakupan yang lebih luas bagi analis. Hasil ini juga sesuai dengan hasil penelitian yang dilakukan oleh Christanti dan Mahastanti (2011) yang menemukan bahwa terdapat beberapa alasan investor melakukan investasi pada suatu perusahaan dengan pertimbangan utama adalah pemberitaan atau ulasan di media keuangan dan pemberitaan atau ulasan di media umum.

H2 : Pengeluaran biaya untuk kegiatan tanggung jawab sosial perusahaan saat ini berpengaruh signifikan positif terhadap prospek kinerja keuangan perusahaan.

\section{Pengungkapan Kegiatan CSR dan Prospek Kinerja Keuangan Perusahaan (CSR as a Signal)}

Beberapa hasil penelitian terdahulu menemukan bahwa terdapat hubungan yang signifikan antara pengungkapan kegiatan CSR dengan kinerja keuangan perusahaan. Salah satunya adalah penelitian yang dilakukan oleh Salehi et al. (2017) menyimpulkan bahwa terdapat hubungan antara pengungkapan CSR oleh perusahaan dan kinerja keuangan perusahaan pada seluruh perusahaan dari setiap sektor 
industri di negara Iran. Hal ini ditunjukan dengan adanya hubungan yang positif dan signifikan antara pengungkapan kegiatan tanggung jawab sosial perusahaan dengan nilai ROA perusahaan. Penelitian lainnya yang menunjukkan hasil signifikan positif antara pengungkapan pelaporan CSR dengan kinerja keuangan perusahaan juga telah dilakukan oleh Feng, Wang, dan Kreuze (2017) pada perusahaan di Amerika Serikat. Pada penelitian ini ditemukan bahwa pelaksanaan CSR yang diukur dengan environment oriented dan social oriented memiliki hubungan signifikan positif terhadap kinerja keuangan perusahaan yang diukur dengan nilai ROA dan Tobin's Q.

H3 : Pengungkapan kegiatan tanggung jawab sosial perusahaan saat ini berpengaruh signifikan positif terhadap prospek kinerja keuangan perusahaan.

\section{Metode Penelitian}

Pada penelitian ini digunakan jenis data kuantitatif yang merupakan data sekunder dari laporan keuangan masing-masing perusahaan. Data yang digunakan terdiri dari environmental, social, dan governance scoring (ESG scoring), environmental scoring, dan social scoring untuk proksi kegiatan CSR, sedangkan kinerja keuangan menggunakan proksi return on asset (ROA), return on equity (ROE), cash flow from operating activities (CFO), dan Tobin's Q. Masing-masing proksi ini diambil dari Bloomberg dan laporan tahunan perusahaan. Data yang akan digunakan merupakan data perusahaan sejak tahun 2011 sampai dengan tahun 2017 yang terdiri dari seluruh perusahaan yang terdaftar di Bursa Efek Indonesia, Singapura, dan Malaysia dan bergerak di sektor sumber daya alam yang terdiri dari sektor agriculture, forest, mining, dan mineral. Data yang mengacu kepada peraturan mengenai pengungkapan CSR yang berlaku di masing-masing negara diambil melalui website lembaga legislatif masing-masing negara.

Data yang digunakan dalam penelitian ini diambil dari Bloomberg berupa rasio dan scoring perusahaan dari industri sumber daya alam dengan subsektor yang terdiri dari perkebunan (agriculture), kehutanan (forest), pertambangan (mining), dan energi dan mineral (energy and mineral) dari tahun 2011 hingga tahun 2017. Seluruh data yang didapatkan diolah menggunakan stata dengan metode regresi berganda. Penelitian ini bertujuan untuk meneliti mengenai hubungan investment in CSR dan CSR as a signal dan future firm performance di perusahaan industri sumber daya alam di Indonesia, Singapura, dan Malaysia. Seluruh variabel dependen yang digunakan dalam penelitian ini menggunakan waktu $\mathrm{t}+1$ untuk menunjukkan prospek kinerja keuangan perusahaan.

Pada hipotesis investment in CSR dan CSR as a signal terdapat dua variabel independen yang akan dipakai dalam pelaksanaan penelitian ini, yaitu optimum CSR dan deviation. Masing-masing variabel independen ini diukur dengan menggunakan beberapa proksi. Lys et al. (2015) menyatakan bahwa investment in CSR dan CSR as a signal dapat dibedakan dengan membagi pengeluaran CSR menjadi dua komponen yaitu, economic based (Optimum CSR) dan unrelated to economic based (deviation). Kedua variabel tersebut dapat diperkirakan dengan persamaan sebagai berikut:

$\widehat{C S R}=\beta_{0}+\beta_{1}$ Firm Factors + $\beta_{2}$ Industry Factors $+\varepsilon$

Pada penelitian ini hanya menggunakan variabel firm factors dikarenakan pemilihan sampel yang sudah memiliki kriteria spesifik industri, sehingga persamaan yang digunakan adalah sebagai berikut:

$$
\widehat{C S R}=\beta_{0}+\beta_{1} \text { Firm Factors }+\varepsilon
$$

Firm factors pada penelitian ini diproksikan dengan beberapa variabel lainnya yaitu, CSR expenses (CSRE), asset turnover 
(ATO), cash flow from operating activities (CFO), cash and cash equivalent (CASH), leverage (LEV), profit margin ( $\mathrm{PM})$, size (SIZE), dan market to book value (MBV). Berikut merupakan persamaan yang digunakan:

$$
\begin{aligned}
\widehat{\mathrm{CSR}}_{\mathrm{it}}=\beta_{0}+\beta_{1} & \mathrm{CSRE}_{\mathrm{it}}+\beta_{2} \mathrm{ATO}_{\text {it }} \\
& +\beta_{3} \mathrm{CASH}_{\mathrm{it}}+\beta_{4} \mathrm{CFO}_{\mathrm{t}} \\
& +\beta_{5} \mathrm{LEV}_{\mathrm{it}}+\beta_{6} \mathrm{PM}_{\mathrm{it}} \\
& +\beta_{7} \mathrm{SIZE}_{\mathrm{it}}+\beta_{8} \mathrm{MBV}_{\mathrm{it}} \\
& +\beta_{9} \mathrm{CGS}_{\mathrm{it}}+\widehat{\varepsilon}
\end{aligned}
$$

Pada hasil perhitungan persamaan di atas optimum CSR dan deviation $\left(\widehat{C S R}_{i t}\right.$ dan $\left.\hat{\varepsilon}\right)$ akan digunakan untuk persamaan model 2 . Optimum CSR akan menjelaskan mengenai kondisi ekonomi dari pembiayaan kegiatan CSR secara maksimal, sedangkan deviation akan menjelaskan faktor lainnya di luar kondisi ekonomi untuk menunjukkan kondisi perusahaan.

\section{Model 1 untuk Menguji Hipotesis 1}

$$
\begin{aligned}
& \triangle R O A_{i t+1}=\alpha_{0}+\alpha_{1} E S G_{i t}+\alpha_{2} R O A_{i t-1} \\
& +\alpha_{3} \Delta R O A_{i t}+\varepsilon \\
& \triangle R O E_{i t+1}=\alpha_{0}+\alpha_{1} E S G_{i t}+\alpha_{2} R O E_{i t-1} \\
& +\alpha_{3} \Delta R O E_{i t}+\varepsilon \\
& \Delta C F O_{i t+1}=\alpha_{0}+\alpha_{1} E S G_{i t}+\alpha_{2} C F O_{i t-1} \\
& +\alpha_{3} \Delta C F O_{i t}+\varepsilon \\
& T o b^{\prime} Q_{i t+1}=\alpha_{0}+\alpha_{1} E S G_{i t}+\varepsilon \\
& \triangle R O A_{i t+1}=\alpha_{0}+\alpha_{1} E N V_{i t}+\alpha_{2} R O A_{i t-1} \\
& +\alpha_{3} \Delta R O A_{i t}+\varepsilon \\
& \triangle R O E_{i t+1}=\alpha_{0}+\alpha_{1} E N V_{i t}+\alpha_{2} R O E_{i t-1} \\
& +\alpha_{3} \Delta R O E_{i t}+\varepsilon \\
& \Delta C F O_{i t+1}=\alpha_{0}+\alpha_{1} E N V_{i t}+\alpha_{2} C F O_{i t-1} \\
& +\alpha_{3} \Delta C F O_{i t}+\varepsilon \\
& T o b^{\prime} Q_{i t+1}=\alpha_{0}+\alpha_{1} E N V_{i t}+\varepsilon \\
& \triangle R O A_{i t+1}=\alpha_{0}+\alpha_{1} S O C_{i t}+\alpha_{2} R O A_{i t-1} \\
& +\alpha_{3} \Delta R O A_{i t}+\varepsilon \\
& \triangle R O E_{i t+1}=\alpha_{0}+\alpha_{1} S O C_{i t}+\alpha_{2} R O E_{i t-1} \\
& +\alpha_{3} \Delta R O E_{i t}+\varepsilon \\
& \triangle C F O_{i t+1}=\alpha_{0}+\alpha_{1} S O C_{i t}+\alpha_{2} C F O_{i t-1} \\
& +\alpha_{3} \Delta C F O_{i t}+\varepsilon
\end{aligned}
$$

\section{Keterangan:}

ESG: Environmental, Social, and Governance Scoring dari Bloomberg; ENV: Environmental Scoring dari Bloomberg; SOC: Social Scoring dari Bloomberg; ROA: Return on Asset; ROE: Return on Equity; CFO: Cash flow from operating activities; TOB: Tobin's Q.

Model 2 untuk Menguji Hipotesis 2 dan 3

$$
\begin{aligned}
& \triangle R O A_{i t+1}=\alpha_{0}+\alpha_{1} \widehat{C_{S R}}+\alpha_{2} \hat{\varepsilon}_{i t}+ \\
& \alpha_{3} \Delta R O A_{i t}+\alpha_{4} R O A_{i t-1}+\alpha_{5} D P S_{i t}+\varepsilon \\
& \triangle R O E_{i t+1}=\alpha_{0}+\alpha_{1} \widehat{C S R_{i t}}+\alpha_{2} \hat{\varepsilon}_{i t}+ \\
& \alpha_{3} \Delta R O E_{i t}+\alpha_{4} R O E_{i t-1}+\alpha_{5} D P S_{i t}+\varepsilon \\
& \triangle C F O_{i t+1}=\alpha_{0}+\alpha_{1} \widehat{C S R} \widehat{R}_{i t}+\alpha_{2} \hat{\varepsilon}_{i t}+ \\
& \alpha_{3} \Delta C F O_{i t}+\alpha_{4} C F O_{i t-1}+\alpha_{5} D P S_{i t}+\varepsilon \\
& T o b^{\prime} Q_{i t+1}=\alpha_{0}+\alpha_{1} \widehat{C S R_{i t}}+\alpha_{2} \hat{\varepsilon}_{i t} \\
& +\alpha_{3} D P S_{i t}+\varepsilon
\end{aligned}
$$

\section{Keterangan:}

ESG: Environmental, Social, and Governance Scoring; ENV: Environmental Scoring; SOC: Social Scoring; ROA: Return on Asset; ROE: Return on Equity; CFO: Cash flow from operating activities; TOB:

Tobin's Q; DPS: Dividend per share; $\widehat{C S R}$ : Nilai kegiatan CSR perusahaan; $\hat{\varepsilon}$ : error dari hasil regresi persamaan $\widehat{C S R}$.

Pada model 1 Tobin's Q tidak menggunakan variabel kontrol seperti ketiga persamaan lainnya. Hal ini dilakukan karena pada kondisi semi-strong efficient market, nilai pasar dapat mencerminkan performa perusahaan secara lebih lengkap, sehingga tidak diperlukan data dari tahun sebelumnya (Lys et al., 2015). Selain itu, pada model 1 digunakan nilai $\mathrm{a}_{1}$ dengan arah negatif (-) atau $\alpha_{1}<0$ sedangkan pada model 2 digunakan nilai $a_{1}$ dengan arah positif (+) atau $\alpha_{1}>0$ akan digunakan untuk investment hypothesis dan $\alpha_{2}$ dengan arah positif (+) atau $\alpha_{2}>0$ untuk signaling hypothesis. 


\section{Hasil Penelitian dan Pembahasan}

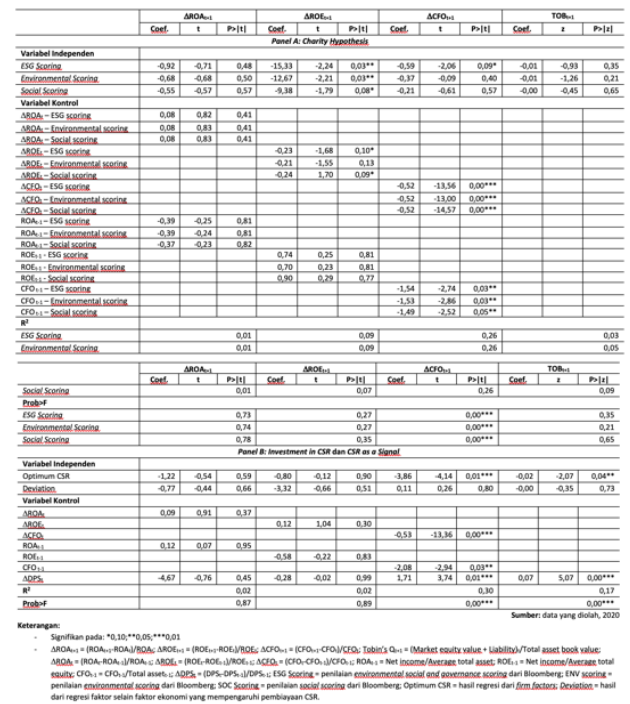

\section{Gambar 2}

\section{Hasil Uji Hipotesis}

Sumber: data yang diolah, 2020

Berdasarkan hasil yang didapatkan diketahui bahwa terdapat beberapa hasil uji hipotesis yang didapatkan tidak sesuai dengan hipotesis yang dikembangkan dalam penelitian ini. Hasil tidak signifikan pada hipotesis 1 , tidak sesuai dengan hipotesis yang dikembangkan pada penelitian ini. Didapatkan bahwa pengeluaran biaya kegiatan CSR dan prospek kinerja keuangan perusahaan yang diproksikan dengan perubahan return on asset $\left(\Delta \mathrm{ROA}_{\mathrm{t}+1}\right)$ dan juga nilai Tobin's $\mathrm{Q}$ perusahaan tidak memiliki hubungan yang signifikan. Lys et al. (2015) menjelaskan bahwa tidak adanya hubungan antara pengeluaran biaya kegiatan CSR dan prospek kinerja keuangan perusahaan maka hal ini mengindikasikan bahwa kegiatan CSR dilaksanakan semata-mata hanya merupakan kegiatan yang bersifat sukarela. Hasil ini juga sama dengan teori yang dikembangkan oleh Garriga dan Melè pada tahun 2004, bahwa kegiatan CSR mencakup hubungan antara perusahaan dengan masyarakat dalam menjaga kebutuhan akan etika dan moral dalam melaksanakan kegiatan usahanya, teori ini dikenal dengan sebutan ethical theory.

Berbeda dengan hasil uji hipotesis yang diproksikan dengan perubahan return on asset $\left(\Delta \mathrm{ROA}_{\mathrm{t}+1}\right)$ dan nilai Tobin's $\mathrm{Q}$ perusahaan, hasil uji hipotesis dengan proksi perubahan return on equity $\left(\Delta \mathrm{ROE}_{\mathrm{t}+1}\right)$ dan perubahan cash flow from operating activities $\left(\Delta \mathrm{CFO}_{\mathrm{t}+1}\right)$ menunjukkan adanya hubungan negatif signifikan terhadap pengeluaran biaya kegiatan CSR. Arah yang negatif ini mengindikasikan bahwa kegiatan CSR yang dilakukan oleh perusahaan memang benar merupakan kegiatan sukarela. Hal ini dikarenakan perusahaan rela untuk mengalami penurunan pada prospek kinerja keuangan perusahaan untuk tetap melaksanakan kegiatan CSR.

Hasil uji hipotesis menunjukkan bahwa kegiatan CSR yang dilaksanakan di ketiga negara masih cenderung bersifat sukarela, namun pada kenyataannya di Indonesia, Singapura, dan Malaysia kegiatan CSR merupakan sesuatu yang telah diatur oleh pemerintah (mandatory). Hal ini mengindikasikan bahwa perusahaan hanya melakukan kegiatan CSR karena kegiatan tersebut merupakan suatu kewajiban untuk mengikuti peraturan yang ada tanpa mengharapkan suatu timbal balik. Meskipun kegiatan CSR di ketiga negara bersifat mandatory atau wajib, tetapi ditemukan bahwa masih banyak perusahaan yang belum memiliki nilai ESG scoring, environmental scoring, dan social scoring. Hal ini disebabkan karena pelaporan kegiatan CSR di ketiga negara masih belum memiliki acuan yang jelas. Pihak pemerintahan di ketiga negara hanya memberikan anjuran untuk menggunakan format yang dikeluarkan oleh Global Reporting Initiative (GRI) dan bukan sebuah keharusan. Kondisi ini sesuai dengan teori yang dijelaskan oleh Carroll (1970) bahwa legal responsibilities adalah kondisi ketika perusahaan harus memenuhi aturan atau hukum yang berlaku dalam 
melaksanakan tanggung jawabnya dalam memenuhi tujuan ekonomi.

Selanjutnya ditemukan hasil $\alpha_{1}$ (optimum CSR) negatif $\left(\alpha_{1}<0\right)$ yang ditemukan pada hubungan kegiatan CSR dan prospek kinerja keuangan perusahaan menunjukkan bahwa hasil ini tidak sesuai dengan hipotesis investment in CSR $\left(\alpha_{1}>0\right)$. Hasil ini mengindikasikan bahwa semakin besar nilai pengeluaran biaya untuk kegiatan CSR maka akan diikuti dengan adanya penurunan nilai prospek kinerja keuangan perusahaan. Hasil negatif juga telah didapati oleh beberapa hasil penelitian terdahulu. Penelitian tersebut dilakukan oleh Friedman (1970); Cornell dan Shapiro (1987); Brammer and Millington (2008); dan Tang et al.,(2012) dalam Chen, Feldman, dan Tang (2015) yang menyatakan bahwa pengeluaran biaya untuk kegiatan CSR akan memberikan dampak negatif terhadap kinerja keuangan perusahaan. Hal ini terjadi karena semakin tinggi pengeluaran untuk biaya pelaksanaan kegiatan CSR, maka akan semakin tinggi pula harga dari produk yang ditawarkan oleh perusahaan. Hal ini akan menyebabkan berkurangnya proporsi pangsa pasar yang dimiliki oleh perusahaan dan akhirnya akan berdampak pada kinerja keuangan perusahaan. Di lain sisi Lys et al. (2015) juga menyatakan bahwa dengan adanya hubungan negatif ini tidak sepenuhnya menunjukkan terjadinya penurunan prospek kinerja keuangan perusahaan, namun hal tersebut disebabkan karena return yang didapatkan oleh perusahaan lebih kecil dibandingkan dengan pengeluaran biaya untuk kegiatan CSR.

Tidak diterimanya hasil pengujian hipotesis 2 juga dapat diakibatkan oleh fakta bahwa pelaksanaan kegiatan CSR di Indonesia, yang mendominasi sampel pada penelitian ini, masih kurang efektif karena adanya pemikiran bahwa kegiatan CSR hanya akan menambah beban perusahaan dibandingkan dengan investasi masa depan (Waagstein, 2010). Selain itu, peraturan mengenai kegiatan CSR di Indonesia hanya memberikan kejelasan yang terbatas mengenai tujuan, arahan, dan implementasi dari kegiatan CSR (Devie et al., 2018). Selain itu, pada hasil penelitian yang telah dilakukan oleh Devie et al. pada tahun 2018 juga menemukan bahwa di Indonesia masih banyak terjadi masalah mengenai hukum dan sosial seperti lemahnya pelaksanaan hukum dan masih maraknya tindakan korupsi.

Hasil uji hipotesis yang selanjutnya adalah untuk hipotesis ketiga yaitu, CSR as a signal. Diketahui bahwa hipotesis ketiga menggunakan variabel independen deviation dan variabel dependen berupa prospek kinerja keuangan perusahaan yang diproksikan dengan perubahan return on asset tahun berikutnya $\left(\Delta \mathrm{ROA}_{\mathrm{t}+1}\right)$, perubahan return on equity tahun berikutnya $\left(\Delta \mathrm{ROE}_{\mathrm{t}+1}\right)$, perubahan cash flow from operating activites $\left(\Delta \mathrm{CFO}_{\mathrm{t}+1}\right)$, dan nilai Tobin's Q. Hasil uji hipotesis pada seluruh variabel dependen menunjukkan hasil yang tidak signifikan. Hal ini sesuai dengan hasil penelitian terdahulu yang telah dilakukan oleh Hackston dan Milne (1996), pada hasil penelitian tersebut ditemukan bahwa tidak terdapat hubungan yang signifikan antara pelaporan kegiatan CSR terhadap kinerja keuangan perusahaan yang diproksikan dengan nilai profitabilitas perusahaan. Hal ini terjadi karena ukuran perusahaan dianggap menjadi sesuatu yang lebih penting dibandingkan dengan nilai profitabilitas perusahaan (Hackston dan Milne, 1996).

$$
\text { Meskipun ditemukan hasil }
$$
hubungan yang tidak signifikan, namun pada hasil uji terhadap perubahan cash flow from operating activities $\left(\Delta \mathrm{CFO}_{\mathrm{t}+1}\right)$ menunjukkan adanya hubungan yang positif $\left(\alpha_{2}>0\right)$. Hasil $\alpha_{2}$ (deviation) yang menunjukkan nilai lebih besar dari nol (0) mengindikasikan bahwa hipotesis CSR as a signal dapat diterima. Menurut Lys et al. (2015), hasil ini menunjukkan bahwa hubungan antara kegiatan CSR dengan prospek kinerja keuangan perusahaan 
mengutamakan tujuan untuk memberikan sinyal kepada para pemangku kepentingan.

Salehi et al. (2017) juga menemukan bahwa perusahaan yang melaksanakan kegiatan CSR akan memperoleh citra positif bagi perusahaan yang dapat mengangkat nilai perusahaan. Meningkatnya nilai perusahaan dapat dimanfaatkan oleh perusahaan untuk menarik perhatian investor pada saat menanamkan dana pada perusahaan tersebut, sehingga perusahaan dapat menggunakan kegiatan CSR menjadi keunggulan perusahaan dibandingkan dengan perusahaan lainnya (competitive advantage) yang dapat mempengaruhi kinerja keuangan.

Hipotesis 3 pada penelitian ini ditolak, disebabkan oleh tidak diwajibkannya pelaporan untuk kegiatan CSR di ketiga negara. Indonesia, Singapura, dan Malaysia hanya menganjurkan penggunaan framework GRI untuk pelaporan kegiatan CSR. Hasil tersebut sesuai dengan hasil yang telah dilakukan oleh Yamagami dan Kokubu (1991) serta Lynn (1992) dalam Widaryanti (2007) menemukan bahwa pengungkapan kegiatan CSR di Asia masih lebih rendah dibandingkan negara di kawasan Amerika dan Eropa. Selain itu, hasil ini juga mengindikasikan bahwa kesadaran masyarakat akan pentingnya pelaporan kegiatan CSR di ketiga negara masih cukup rendah.

\section{Simpulan dan Saran}

\section{Simpulan}

Di bawah ini merupakan hasil yang didapatkan dari uji hipotesis yang telah dilakukan dalam penelitian ini:

1. Ditemukan bahwa pengeluaran biaya kegiatan CSR mempunyai hubungan yang signifikan dan tidak signifikan dengan arah negatif terhadap prospek kinerja keuangan perusahaan. Hasil yang menunjukkan arah yang negatif $\left(\alpha_{1}<0\right)$ mengindikasikan bahwa kegiatan CSR yang dilaksanakan di ketiga negara merupakan kegiatan yang bersifat sukarela. Hal ini dikarenakan perusahaan tetap melakukan kegiatan CSR meskipun ditemukan tidak adanya hubungan yang signifikan dan hubungan negatif signifikan terhadap prospek kinerja keuangan perusahaan.

2. Pengeluaran biaya kegiatan CSR memiliki hubungan signifikan dan tidak signifikan dengan arah negatif terhadap prospek kinerja keuangan perusahaan. Hasil yang menunjukkan arah negatif mengindikasikan bahwa semakin besar nilai pengeluaran biaya kegiatan CSR maka akan menurunkan kinerja keuangan perusahaan. Hasil ini juga ditemukan oleh Friedman (1970); Cornell dan Shapiro (1987); Brammer and Millington (2008); dan Tang et al.,(2012) dalam Chen, Feldman, dan Tang (2015) yang menyatakan bahwa pengeluaran biaya untuk kegiatan CSR akan menghasilkan efek negatif terhadap performa keuangan perusahaan. Hal ini terjadi akibat biaya untuk kegiatan CSR hanya akan memperbesar beban yang akan ditanggung oleh pihak perusahaan sehingga hal ini menyebkan nilai laba yang dapat dihasilkan oleh perusahaan berkurang.

3. Pelaporan kegiatan CSR memiliki hubungan yang tidak signifikan dengan prospek kinerja keuangan perusahaan dengan arah negatif untuk variabel perubahan return on asset, return on equity, dan nilai Tobin's Q perusahaan. Hasil yang menunjukkan arah negatif $\left(\alpha_{2}<0\right)$ mengindikasikan bahwa hipotesis CSR as a signal tidak dapat diterima, namun hasil hubungan positif $\left(\alpha_{2}>0\right)$ yang ditunjukkan dengan variabel cash flow from operating activities mengindikasikan bahwa hipotesis CSR as a signal dapat diterima. Salehi et al. (2017) juga menyimpulkan bahwa perusahaan 
yang melaksanakan kegiatan CSR akan memperoleh citra positif bagi perusahaan yang dapat mengangkat nilai perusahaan.

Sesuai dengan ketiga penjabaran di atas disimpulkan bahwa hipotesis pertama yaitu, charity hypothesis dapat diterima, sedangkan dua hipotesis lainnya yaitu, hipotesis kedua (investment in CSR) dan hipotesis ketiga (CSR as a signal) tidak dapat diterima.

Tidak sesuainya hasil yang didapatkan dari pengembangan hipotesis dalam penelitian ini adalah karena peraturan yang mengatur mengenai pelaporan kegiatan CSR di ketiga negara masih belum kuat. Ketiga negara memang telah memiliki peraturan yang mengatur mengenai kewajiban bagi para pelaku usaha untuk melaksanakan kegiatan CSR, namun untuk peraturan mengenai pelaporan kegiatan CSR masih belum memiliki landasan yang kuat. Pemerintahan di ketiga negara tersebut hanya merekomendasikan framework yang dapat digunakan oleh pelaku usaha, yaitu sesuai dengan framework yang telah dikeluarkan oleh organisasi Global Reporting Initiative (GRI).

Hal lainnya yang mungkin dapat menjadi alasan tidak didapatkannya hasil yang menunjukkan signifikan positif antara kegiatan tanggungjawab sosial perusahaan dan prospek performa keuangan perusahaan adalah belum adanya sanksi yang tegas dari pihak pemerintahan. Hal ini terbukti dari jenis sanksi yang diberikan kepada para pelaku usaha hanya berupa sanksi administratif, yaitu dalam bentuk surat teguran bagi pelaku usaha yang tidak melaksanakan kegiatan CSR. Sanksi ini dirasa kurang cukup untuk dapat memberikan efek jera bagi pelaku usaha karena surat teguran ini tidak akan memberikan dampak negatif bagi para pelaku usaha.

Berdasarkan penjelasan sebelumnya dapat disimpulkan bahwa pelaku usaha sampai dengan saat ini masih memiliki kepedulian yang cukup rendah terhadap pelaksanaan dan pengungkapan kegiatan CSR. Hal ini dilandasi dengan masih terjadinya fenomena berupa kerusakan lingkungan yang disebabkan oleh pelaku usaha dari ketiga negara dan juga masih maraknya kegiatan korupsi di Indonesia dan Malaysia. Lingkungan dan kegiatan korupsi sendiri merupakan salah satu aspek yang diatur dalam framework yang dikeluarkan oleh Global Reporting Initiative (GRI). Sehingga tidak dapat dipungkiri bahwa kegiatan CSR yang dilakukan tidak hanya berfokus pada aspek lingkungan, tetapi juga aspek ekonomi dan sosial.

\section{Saran}

Penelitian ini memiliki beberapa keterbatasan, salah satunya adalah keterbatasan dalam mendapatkan kelengkapan data scoring maupun data mengenai pengeluaran biaya yang berhubungan dengan kegiatan CSR (advertising expense dan research and development expense), sehingga pada penelitian selanjutnya diharapkan dapat menggunakan sektor lainnya. Hal ini dikarenakan pada sektor SDA kedua biaya tersebut tidak relevan dengan kegiatan bisnis perusahaan. Selain itu, ditemukannya hasil yang tidak signifikan dan signifikan negatif juga dapat menjadi pertimbangan untuk memperpanjang waktu penelitian, seperti 2 atau 3 tahun ke depan. Penelitian selanjutnya juga dapat mempertimbangkan untuk menggunakan variabel lainnya seperti ukuran perusahaan.

Selain itu, berdasarkan hasil penelitian yang menunjukkan bahwa kegiatan CSR di ketiga negara hanya dilakukan semata-mata untuk memenuhi aturan yang telah dibuat oleh pihak pemerintahan, maka penelitian ini memiliki implikasi dengan tujuan utama adalah pihak regulator. Pihak regulator diharapkan dapat lebih tegas kepada perusahaan yang melanggar peraturan mengenai pelaksanaan dan pelaporan kegiatan CSR. Selain itu, 
untuk dapat meningkatkan daya tarik perusahaan dalam menjalankan kegiatan CSR maka pemerintah dapat memberikan penghargaan kepada perusahaan yang telah menjalankan peraturan tersebut.

Selain pihak regulator, pihak investor juga dapat membantu pihak regulator untuk dapat mendorong pihak manajemen untuk lebih serius dalam melaksanakan kegiatan CSR dengan cara lebih memperhatikan perusahaan yang telah melaksanakan kegiatan CSR. Selanjutnya, pihak manajemen juga dapat mempertimbangkan keuntungan dengan dilaksanakannya kegiatan CSR, bukan hanya keuntungan dari sisi profitabilitas, tetapi juga keuntungan dari sisi competitive advantage. Penelitian ini juga dapat memberikan tambahan wawasan mengenai hubungan antara pelaksanaan dan pengungkapan kegiatan CSR dengan prospek kinerja keuangan perusahaan, bahwa kegiatan CSR merupakan kegiatan yang bersifat sukarela.

\section{Daftar Pustaka}

About SGX Regulation. (2019, November 14). Retrieved from SGX Web site: https://www2.sgx.com/regulation/ab out-sgx-regco

Allen, F., \& Michaely, R. (2003). Payout Policy. In Handbook of the Economics of Finance (pp. 339422). United States: Elsevier.

ASEAN Cooperation on Environment. (2019, December 05). Overview: ASEAN Socio-Cultural Community. Retrieved from ASEAN Web site: https://asean.org/asean-sociocultural/asean-ministerial-meetingon-environment-amme/overview/

Barnett, M. L. (2007). Stakeholder Influence Capacity and the Variability of Financial Returns to Corporate Social Responsibility. Academy of Management, 794-816.
Bhattacharyya, A., \& Rahman, M. L. (2019). Mandatory CSR expenditure and firm performance. Jounal of Contemporary Accounting and Economics.

Brammer, S., \& Millington, A. (2008). Does It Pay to be Different? An Analysis of The Relationship Between Corporate Social and Financial Performance. Strategic Management Journal.

Brigham, E. F., \& Houston, J. F. (2009). Fundamentals of Financial Management, 12th edition. United States of America: South-Western CENAGE Learning.

Buchdadi, A. D., Oktafianto, E., \& Mardiyati, U. (2018). Pengaruh R\&D Expenditure terhadap Firm Performance Perusahaan yang Terdaftar di BEI Periode 2003-2015. Riset Manajemen Sains Indonesia, 338.

Business. (2019, November 14). Retrieved from The Phnom Penh Post: https://www.phnompenhpost.com/bu siness/corporate-socialresponsibility-cambodia

Carroll, A. B. (1979). A Three-Dimensional Conceptual Model of Corporate Performance. Academic of Management Review, 500-501.

Chen, L., Feldmann, A., \& Tang, O. (2015). The relationship between disclosures of corporate social performance and financial performance: Evidences from GRI reports in manufacturing industry . Production Economics, 445-456.

Ching, H., \& Gerab, F. (2015). Sustainability Reports in Brazil through the Lens of Signaling, Legitimacy and Stakeholder Theories. Social Responsibility Journal, 95-110.

Christanti, N., \& Mahastanti, L. A. (2011). Faktor-Faktor yang Dipertimbangkan Investor dalam 
Melakukan Investasi . Manajemen Teori dan Terapan, 44.

CNN Indonesia. (2019, December 05). CNN Indonesia: International. Retrieved from CNN Indonesia Web site:

https://www.cnnindonesia.com/inter nasional/20190119170046-108362158/hilangnya-pasir-di-sungaimekong/8.

CNN Indonesia. (2019, Juli 13). Retrieved from CNN Indonesia Web site: https://www.cnnindonesia.com/nasio $\mathrm{nal} / 20190913192412-20$ -

430374/menteri-lhk-3-perusahaanmalaysia-terlibat-pembakaran-hutan

Cochran, P. L., \& Wood, R. A. (1984). Corporate Social Responsibility and Financial Performance. Academy of Management Journal, 42-56.

Cornell, B., \& Shapiro, A. C. (1987). Corporate Stakeholder and Corporate Finance. Financial Management, 5-14.

Dainelli, F., Bini, L., \& Giunta, F. (2013). Signaling strategies in annual reports: Evidence from the disclosure of performance indicators. Advances in Accounting, incorporating Advances in International Accounting 29, 267277.

Devie, D., Liman, L. P., Tarigan, J., \& Jie, F. (2018). Corporate Social Responsibility, Financial Performance, and Risk in Indonesia Natural Resources Industry. Social Responsibility Journal.

Doh, J. P., Howton, S. D., Howton, S. W., \& Siegel, D. S. (2010). Does the Market Respond to an Endorsement of Social Responsibility? The Role of Institutions, Information, and Legitimacy . Journal of Management, 1461-1485.

Feng, M., Wang, X., \& Kreuze, J. G. (2017). Corporate social responsibility and firm financial performance Comparison analyses across industries and CSR categories. Journal of Business, 106133.

Friedman, M. (1970). The Social Responsibility of Business is to Increase its Profits. The New York Times Magazine.

Garriga, E., \& Melé, D. (2004). Corporate Social Responsibility Theories: Mapping the Territory. Journal of Business Ethics.

Ghozali, Imam. (2016). Aplikasi Analisis Multivariate Dengan Program IBM SPSS 23 (Edisi 8). Cetakan ke VIII. Semarang : Badan Penerbit Universitas Diponegoro.

Giannarakis, G., Konteos, G., Zafeiriou, E., \& Partalidou, X. (2016). The Impact of Corporate Social Responsibility on Financial Performance. Investment Management and Financial Innovation.

Gujarati, D. N., \& Porter, D. C. (2003). Basic Econometrics. United States of America: McGraw-Hill

Hackston, D., \& Milne, M. J. (1996). Some Determinants of Social and Environmental Disclosure in New Zealand Companies. Accounting, Auditing \& Accountability Journal, 77-108.

Hanna, S. A. (2020, Juli 23). Retrieved from $\mathrm{CNN}$ Indonesia: https://www.cnnindonesia.com/inter nasional/20160310193052-106116657/mahathir-korupsi-malaysiamelebihi-indonesia

Herremans, I. M., Akathaporn, P., \& Mcinnes, M. (1993). An Investigation Of Corporate Social Responsibility Reputation And Economic Performance. Accounting Organizations and Society, 587-604.

Hutchinson, M., \& Gul, F. A. (2004). Investment opportunity set, corporate governance practices and firm performance. Journal of Corporate Finance, 596-614. 
Janamrung, B., \& Issarawornrawanich, P. (2015). The association between corporate social responsibility index and performance of firms in industrial products and resources industries: empirical evidence from Thailand. Social Responsibility Journal, 893-903.

Jenkins, H., \& Yakovleva, N. (2006). Corporate Social Responsibility in the Mining Industry: Exploring Trends in Social and Environmental Disclosure. Journal of Cleaner Production, 271-284.

Kang, K. H., Huh, C., \& Lee, S. (2009). Impacts of positive and negative corporate social responsibility activities on company performance in the hospitality industry. International Journal of Hospitality Management, 72-82.

Keim, G. D. (1978). Corporate Social Responsibility: An Assessment of the Enlightened Self-Interest Model. Academy of Management, 32-39.

KsiężaK, P., \& Fischbach , B. (2017). Triple Bottom Line: The Pillars of CSR. Journal of Corporate Responsibility and Leadership, 96110.

Laskar, N., \& Maji, S. G. (2018). Disclosure of Corporate Sustainability Performance and Firm Performance in Asia. Asian Review of Accounting, 414-443.

Legislative Information. (2019, November 14). Retrieved from House of Representatives: http://www.congress.gov.ph/legisdo cs/basic_16/HB00306.pdf

Lilianti, E. (2018). Pengaruh Dividend Per Share (DPS) dan Earning Per Share (EPS) terhadap Harga Saham pada Perusahaan Sub Sektor Farmasi di Bursa Efek Indonesia (BEI). Journal Ecoment Global, 13-14.

Lin, L., Hung, P.-H., Chou, D.-W., \& Lai, C. W. (2017). Financial Performance and Corporate Social Responsibility:
Empirical Evidence from Taiwan. Asia Pacific Management Review, 61-71.

Lloyd, R. A. (2017). The Impact of CSR Effort on Firm Performance in The Energy Sector. Integrative Business and Economics, 25-26.

Lys, T., Naughton, J. P., \& Wang, C. (2015). Signaling Through Corporate Accountability Reporting. Accounting and Economics , 56-72.

Margolis, J. D., Elvenbein, H. A., \& Walsh, J. P. (2007). Does It Pay to be Good? A Meta-Analysis and Redirection of Reseach on the Relationship between Corporate Social and Financial Performance.Working Paper Harvard Business School Boston.

McWilliams, A., \& Siegel, D. (2001). CSR and Financial Performance: Correlation or Misspecification? Strategic Management Journal, 603609.

Murray, K. B., \& Montanari, J. R. (1986). Strategic Management of the Socially Responsible Firm: Integrating Management and Marketing Theory. Academy of Management, 815-827.

Nugrahanti, Y. W., \& Maharani, O. (2003). Karakteristik Perusahaan terhadap Pengungkapan Corporate Social Responsibility (CSR) dan Dampaknya terhadap Kinerja Keuangan. Manajemen dan Bisnis, 128-129.

Peraturan OJK. (2019, November 14). Retrieved from Otoritas Jasa Keuangan Web site: https://www.ojk.go.id/id/kanal/perba nkan/regulasi/peraturanojk/Pages/POJK-PenerapanKeuangan-Berkelanjutan-bagiLembaga-Jasa-Keuangan,-Emiten,dan-Perusahaan-Publik.aspx

Prihadi, T. (2013). 7 Deteksi Cepat Kondisi Keuangan dan 7 Analisis Rasio Keuangan. Jakarta: PPM. 
Purnomo, P. K., \& Widianingsih, L. P. (2012). The Influence of Environmental Performance on Financial Performance with Corporate Social Responsibility (CSR) Disclosure as a Moderating Variable: Evidence from Listed Companies in Indonesia. Business and Economics, 57-69.

Rakhiemah, A. N., \& Agustia, D. (2009). Pengaruh Kinerja Lingkungan Terhadap Corporate Social Responsibility (CSR) Disclosure dan Kinerja Financial Perusahaan Manufaktur yang Terdaftar di Bursa Efek Indonesia. Simposium Nasional Akuntansi XII, 13.

Regulation. (2019, November 19). Retrieved from Bursa Malaysia Web site:

https://www.bursamalaysia.com/reg ulation/listing_requirements/main_m arket/practice_notes

Salehi, M., Dashtbayaz, L. M., \& Khorashadizadeh, S. (2017). Corporate Social Responsibility and Future Financial Performance. Journal of Business.

ŞAMİLOĞLU, F., ÖZTOP, A. O., \& KAHRAMAN, Y. E. (2017). The Determinants of Firm Financial Performance: Evidence From Istanbul Stock Exchange (BIST). Journal of Economics and Finance, 62-67.

Sami, H., Wang, J., \& Zhou, H. (2011). Corporate Governance and Operating Performance of Chinese Listed Firms. International Accounting, Auditing and Taxation, 110-113.

Shane, P. B., \& Spicer, B. H. (1983). Market Response to Environmental Information Produced Outside the Firm. Accounting, 521-538.

Sloan, R. G. (1996). Do Stock Prices Fully Reflect Information in Accruals and Cash Flows about Future Earnings? The Accounting Review, 289-315.
Su, W., Peng, M. W., Tan, W., \& Cheung, Y. L. (2014). The Signaling Effect of Corporate Social Responsibility in Emerging Economies. Journal Business Ethics.

Subramanyam, K. R. (2014). Financial Statement Analysis. California: McGraw Hill Education.

Sudiyatno, B., \& Puspitasari, E. (2010). Tobin's Q and Altman Z-Score as Indicators of Performance Measurement Company. Accounting, 9-21.

Sustainable Development of Listed Companies. (2019, November 14). Retrieved from SET Web site: https://www.set.or.th/sustainable_de v/en/sr/sd/report_p1.html

Tang, Z., Hull , C. E., \& Rothenberg, S. (2012). How Corporate Social Responsibility Engagement Strategy Moderates the CSR-Financial Performance Relationshipjoms_1068 1274..1303. Journal of Management Studies, 1275-1303.

Thatcher, M. E., \& Pingry, D. E. (2009). Optimal Policy for Software Patents: Model and Comparative Implications. Journal of Management Information System, 103-133.

Undang-Undang. (2019, November 14). Retrieved from Otoritas Jasa Keuangan Web site: https://www.ojk.go.id/sustainablefinance/id/peraturan/undangundang/Pages/Undang-Undang-No.40-tahun-2007-tentang-PerseroanTerbatas.aspx

Widaryanti. (2007). Analisis Pengaruh Pengungkapan Tanggung Jawab Sosial Perusahaan terhadap Kinerja Keuangan. Fokus Ekonomi, 37-38.

Widiastuty, E., \& Soewarno, N. (2019). CSR Expenditure and Company Performance: Charity or Signal? Evidence from Indonesia. Quality Innovation Prosperity, 23-37. 
Jurnal Akuntansi匹 Volume 13 Nomor 1, Mei 2021 : 118 - 133

World Wildlife Fund. (2019, December 05). WWF Indonesia: News \& Facts. Retrieved from WWF Indonesia Web site: https://www.wwf.or.id/en/news_fact s/?uNewsID $=38842$

Yamagami, T., \& Kokubu, K. (1991). A Note on Corporate Social Disclosure in Japan. Accounting, Auditing \& Accountability Journal. 